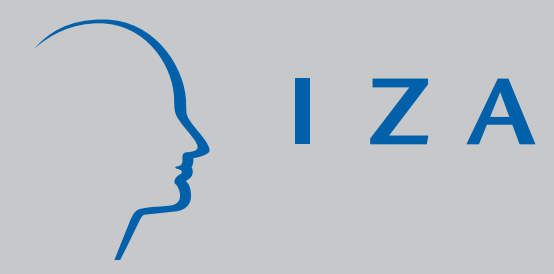

IZADP No. 3388

Measuring Skilled Emigration Rates:

The Case of Small States

Frédéric Docquier

Maurice Schiff

March 2008 


\title{
Measuring Skilled Emigration Rates: The Case of Small States
}

\author{
Frédéric Docquier \\ FNRS, IRES, Catholic University of Louvain \\ and IZA \\ Maurice Schiff \\ World Bank \\ and IZA
}

Discussion Paper No. 3388

March 2008

\author{
IZA \\ P.O. Box 7240 \\ 53072 Bonn \\ Germany \\ Phone: +49-228-3894-0 \\ Fax: +49-228-3894-180 \\ E-mail: iza@iza.org
}

\begin{abstract}
Any opinions expressed here are those of the author(s) and not those of IZA. Research published in this series may include views on policy, but the institute itself takes no institutional policy positions.

The Institute for the Study of Labor (IZA) in Bonn is a local and virtual international research center and a place of communication between science, politics and business. IZA is an independent nonprofit organization supported by Deutsche Post World Net. The center is associated with the University of Bonn and offers a stimulating research environment through its international network, workshops and conferences, data service, project support, research visits and doctoral program. IZA engages in (i) original and internationally competitive research in all fields of labor economics, (ii) development of policy concepts, and (iii) dissemination of research results and concepts to the interested public.
\end{abstract}

IZA Discussion Papers often represent preliminary work and are circulated to encourage discussion. Citation of such a paper should account for its provisional character. A revised version may be available directly from the author. 
IZA Discussion Paper No. 3388

March 2008

\section{ABSTRACT}

\section{Measuring Skilled Emigration Rates: The Case of Small States ${ }^{*}$}

Recent changes in information and communication technologies (ICT) have contributed to a dramatic increase in the integration and interdependence of countries, markets and people. This paper focuses on an increasingly important aspect of globalization, the international movement of people, with emphasis on the mobility of skilled people. This issue is of great concern for the many small states that experience huge brain drain levels.

JEL Classification: F22

Keywords: $\quad$ migration, skilled, brain drain, small states, evidence

Corresponding author:

Maurice Schiff

DECRG (MC3-303)

World Bank

1818 H Street NW

Washington, DC 20433

USA

E-mail: mschiff@worldbank.org

\footnotetext{
* This paper was presented at the World Bank Conference on "Small States, Growth Challenges and Development Solutions", Research Program on Economic Growth and Integration of Small States in the World Economy, PREMED, World Bank, Washington, December 7-8, 2006. We thank David McKenzie and Edgardo Favaro for their comments. The views expressed here are those of the authors and do not necessarily reflect those of the World Bank, its Executive Directors or the governments they represent.
} 


\section{INTRODUCTION}

The 1960s and 1970s saw great interest in international migration issues. Interest in the topic abated in the following years. However, with growth in migration ${ }^{1}$ and remittance flows accelerating in recent years, interest has reappeared by source and host country analysts and policy makers, as well as in academia and multilateral, regional and bilateral development institutions (Ozden and Schiff 2006).

The main question addressed in this paper is the relationship between skilled migration rates and country size. This section presents some stylized facts about the relationship between country size and various aspects of openness (imports, exports, trade, FDI and brain drain), examines various explanations for that relationship as well as a number of issues that are specific to the brain drain.

First, the degree of openness of a country tends to be negatively related to its population size. Simple bivariate regressions show that the semi-elasticity of import/GDP to population size is 7.15, of export/GDP is 3.72, of trade/GDP is 5.43 (simple average), of FDI/GDP is 0.64 and of the brain drain is 5.26. A similar value is obtained for the general emigration rate. These figures indicate that the brain drain is highly sensitive to country size. Its semi-elasticity is greater than that of exports and FDI, smaller than that of imports, and about the same as that of overall trade.

Second, there are various reasons for the negative relation between skilled migration rates and country size, with small countries showing higher rates, particularly the developing ones:

- Production in small states tends to be highly specialized in a limited number of sectors. Hence, consumers and producers are, respectively, much more dependent on trade for desired consumer goods and intermediate inputs. Thus, demand for a variety of skills is very limited;

- The demand for skilled jobs in small developing countries is likely to be even more limited because of these countries' specialization in the production of commodities (e.g., sugar) which are typically less skill intensive;

- Small countries also tend to be more unstable economically. The high degree of specialization implies a greater vulnerability to fluctuations of the world economy. Second, the fact that production in many of the poorer small developing economies

\footnotetext{
${ }^{1}$ For instance, South-North migration has increased by 30\% from 1990 to 2000 while that of skilled labor has increased by $70 \%$.
} 
tends to be concentrated in commodities makes them even more vulnerable to external economic shocks (because of low demand elasticity and thus high fluctuations in price) as well as to weather shocks.

Third, the brain drain raises a number of major issues that are specific to it.

1. While trade imbalances put in motion mechanisms to restore equilibrium between exports and imports - including exchange rate movements, such mechanisms do not necessarily exist in the case of the movement of skilled labor. Due to technological and institutional differences, migration need not reduce the wage gap between source and host countries. On the contrary, human capital externalities (Lucas 1988) associated with skilled labor migration might even raise the skilled wage gap between source and host countries.

2. Human capital is typically considered to be an important element of the engine of growth. If skilled emigration is not compensated by skilled immigration - an unlikely outcome for most developing source countries -- or by stronger human capital accumulation, source countries may gradually lose their capacity to develop.

3. Though the new literature on the brain drain suggests that skilled emigration may induces positive feedback effects for sending countries (including remittances, increased trade, transfer of knowledge and behavioral modes ${ }^{2}$ ), these tend to be dominated by the direct effect of the brain drain on the stock of human capital (see Beine et al, 2006).

\section{SMALL STATES}

There are many possible ways of defining small states. One can use various criteria (population, GDP, territory size), as well as various thresholds and base years. Unsurprisingly, these criteria are strongly correlated ${ }^{3}$ as cross-country differences are well preserved over time. Here we use the population size in 2000

There is no special significance in the selection of a particular population threshold to define small states. Indeed, the Commonwealth, in its work on small states, uses a threshold of 1.5

\footnotetext{
${ }^{2}$ See Fargues (2006) on the impact of international migration on fertility in the sending countries.

${ }^{3}$ In 2000 , the correlation rate between population and GDP amounted to $78 \%$, and $84 \%$ between population and size.
} 
million people, but it also includes larger member countries (Jamaica, Lesotho, Namibia and Papua New Guinea) because they share many of the same characteristics of smallness. The World Bank Task Force on small states uses the same threshold as a convenient yardstick for classifying all small states, and only consider sovereign states.

Using the standard of a population below 1.5 million people in 2000, 45 developing countries are small (see Alphabetical list of small states by population, population rank \& GNP per capita), accounting for nearly one third of the total number of developing countries. They are home to 20 million people, less than 0.4 percent of the total population of developing countries. They range in size from "micro-states” like Cook Islands, Nauru, Niue, Palau, St. Kitts and Nevis, and Tuvalu (with fewer than 50,000 people each) to Botswana, Gabon, The Gambia, Guinea-Bissau, Mauritius, and Trinidad and Tobago (with more than 1 million people each). The per capita GNP in these countries also ranges widely, from less than $\$ 400$ in several African countries (Comoros, The Gambia, Guinea-Bissau, and Sao Tome and Principe) to just \$700-1,300 in such countries as Cape Verde, Guyana, Kiribati, Maldives, Solomon Islands, and Tuvalu; to more than \$9,000 (The Bahamas, Brunei, Cyprus, Malta, and Qatar). There are small states in every geographic region, but most countries fall into three main groups: twelve states are in the Caribbean region, fourteen in East Asia and Pacific, and twelve in Africa. Of the remaining seven countries, two are in South Asia, two in the Middle East, and three in Europe.

\section{A NEW DATABASE ON EMIGRATION RATES BY EDUCATIONAL ATTAINMENT}

This section describes the methodology and data sources used to compute emigration stocks and rates by educational attainment and by origin country in 1990 and 2000. In what follows, the term "country" usually designates independent states whilst "dependent territory" refers to other entities attached to a particular independent state. Our 2000 data set distinguishes 192 independent territories (Vatican and the 191 UN member states, including East Timor which became independent in 2002) and 39 dependent territories.

Stocks are provided for both types of territories while rates are only provided for independent countries as well as three dependent territories which are treated as countries (Hong Kong, Macao and Taiwan) and one occupied territory (Palestine). Since most Korean migrants to the USA did not accurately report their origin, we cannot distinguish between North and South 
Korea (estimates are provided for Korea as a whole). We distinguish 174 countries in 1990, before the secession of the Soviet block, ex-Yugoslavia, ex-Czechoslovakia, the independence of Eritrea and East-Timor, and the German and Yemen reunifications ${ }^{4}$.

For economic and statistical reasons, working on stocks is more attractive than working on flows. Stock variables are more appropriate to analyze the endogeneity and the dynamics of migration movements (the equilibrium values are often expressed in terms of stocks). Regarding statistics, it has long been recognized that migration flow data are less reliable than stock data, due to the impossibility of evaluating emigration and return migration movements.

We count as migrants all working-aged (25 and over) foreign-born individuals living in an OECD country ${ }^{5}$. Skilled migrants are those with at least tertiary educational attainment wherever they completed their schooling. Our methodology proceeds in two steps. We first compute emigration stocks by educational attainment from all countries of the world. Then, we evaluate these numbers in percentage of the total labor force born in the sending country (including the migrants themselves). This definition deserves two main comments.

First, the set of receiving countries is restricted to OECD nations. Compared to existing works (such as Trends in International Migration - see OECD, 2002), our database provides many insights about the structure of South-North and North-North migration. Generally speaking, the skill level of immigrants in non-OECD countries is expected to be very low, except in a few countries such as South Africa (1.3 million immigrants in 2000), the six member states of the Gulf Cooperation Council (9.6 million immigrants in Saudi Arabia, United Arab Emirates, Kuwait, Bahrain, Oman and Qatar), some Eastern Asian countries (4 million immigrants in Hong-Kong and Singapore only). According to their census and survey data, about 17.5 percent of adult immigrants are tertiary educated in these countries (17 percent in Bahrain, 17.2 percent in Saudi Arabia, 14 percent in Kuwait, 18.7 percent in South Africa).

Considering that children constitute 25 percent of the immigration stock, we estimate the number of educated workers at 1.9 million in these countries. The number of educated immigrants in the rest of the world lies between 1 and 4 million (if the average proportion of educated immigrants among adults lies between 2.5 and 10 percent). This implies that focusing on OECD countries, we should capture a large fraction of the world-wide educated migration (about 90 percent). Nevertheless, we are aware that by disregarding non-OECD

\footnotetext{
${ }^{4}$ Note that we report 1990 estimates for a couple of countries which became independent after January 1, 1990 (Namibia, Marshall Islands, Micronesia, Palau).

${ }^{5}$ Our working-aged concept includes retirees.
} 
immigration countries, we probably underestimate the brain drain for a dozen of developing countries (such as Egypt, Sudan, Jordan, Yemen, Pakistan or Bangladesh in the neighborhood of the Gulf states, Swaziland, Namibia, Zimbabwe and other countries which send emigrants to South Africa, etc.). Incorporating data collected from selected non-OECD countries could refine the data set.

Second, we have no systematic information on the age of entry. It is therefore impossible to distinguish between immigrants who were educated at the time of their arrival and those who acquired education after they settled in the receiving country; for example, Mexican-born individuals who arrived in the US at age 5 or 10 and graduated from US high-education institutions are counted as highly-skilled immigrants. Hence, our definition of the brain drain is partly determined by data availability. Existing data do not allow us to systematically eliminate foreign-born individuals who arrived with completed schooling or after a given age threshold. In the US, the proportion of foreign born individuals who arrived before age 10 represents 10 percent of the immigration stock (16 percent for those who arrived before age 16). This average proportion amounts to 13 percent among skilled immigrants (20.4 for age 16).

Important differences are observed across countries. The share is important for high income and Central American countries (about 20 percent). It is quite low for Asian and African countries (about 9 percent). Having no systematic data for the other receiving countries, we cannot control for familial immigration. Our data base includes these individuals who arrived at young age. Our choice is also motivated by another reason. It is impossible to quantify the share of these young immigrants who were partly educated in their birth country and/or who arrived with foreign fellowships. Young immigrants who spent part of their primary or secondary schooling in the origin country, or who got foreign schooling fellowships induced a fiscal loss for their origin country.

\subsection{Emigration stocks}

It is well documented that statistics provided by origin countries do not provide a realistic picture of emigration. When available, they are incomplete and imprecise ${ }^{6}$. Whilst detailed immigration data are not easy to collect on an homogeneous basis, information on emigration

\footnotetext{
${ }^{6}$ Bhorat et al. (2002) compare South African emigration data to immigration numbers collected in five important receiving countries (Australia, Canada, New Zealand, UK and USA). They show that the emigration sum was approximately 3 times larger than South African official statistics.
} 
can only be captured by aggregating consistent immigration data collected in receiving countries. Information about the origin and skill of natives and immigrants is available from national population censuses and registers. More specifically, country i's census usually identifies individuals on the basis of age, country of birth $j$, and skill level $s$. Our method consists in collecting census or register data from a large set of receiving countries, with the highest level of detail on birth countries and (at least) three levels of educational attainment: $s=h$ for high-skilled, $s=m$ for medium-skilled, $s=l$ for low-skilled and $s=u$ for the unknowns. Let $M_{t, s}^{i, j}$ denote the stock of working-aged individuals born in $j$, of skill $s$, living in country $i$ at time $t$.

Low-skilled workers are those with primary education (or with 0 to 8 years of schooling completed); medium-skilled workers are those with secondary education (9 to 12 years of schooling); high-skilled workers are those with tertiary education (13 years and above). The unknowns are either due to the fact that some immigrants did not declare their educational attainment or to the absence of data on education in some receiving countries. Educational categories are built on the basis of country specific information and are compatible with human capital indicators available for all sending countries. A mapping between the country educational classification is sometimes required to harmonize the data ${ }^{7}$.

By focusing on census and register data, our methodology does not capture illegal immigration for which systematic statistics by education level and country of origin are not available. According to the U.S. Immigration and Naturalization Services, the illegal population residing in the United States amounted to 3.5 million in January 1990 and 7.0 million in January 2000. It is even possible to identify the main countries of origin (in 2000, 68.7 percent were from Mexico, 2.7 from El Salvador, 2.1 from Guatemala, 2.0 from Colombia and Honduras, etc. $)^{8}$. However, there is no accurate data about the educational structure of these illegal migrants. For the other member states of the OECD, data on illegal immigration are less reliable or do not exist. By disregarding illegal migrants, we probably overestimate the average level of education of the immigrant population (it can be reasonably assumed that most illegal immigrants are uneducated). Nevertheless, this limit should not significantly distort our estimates of the migration rate of highly-skilled workers. ${ }^{9}$

\footnotetext{
${ }^{7}$ For example, Australian data mix information about the highest degree and the number of years of schooling.

${ }^{8}$ See http://uscis.gov/graphics/shared/aboutus/statistics/III Report 1211.pdf.

${ }^{9}$ Note that the problem may not be that important for estimation of brain drain determinants because results do not depend on the extent or share of illegal migrants but rather on their cross-country difference. Hence,
} 
As far as possible, we turn our attention to the homogeneity and the comparability of the data. This induces a couple of methodological choices:

- To allow comparisons between 1990 and 2000, we consider the same 30 receiving countries in 1990 and 2000. Consequently, Czechoslovakia, Hungary, Korea, Poland, Mexico and Turkey are considered as receiving countries in 1990 despite the fact that they were not members of the OECD. item Migration is defined on the basis of the country of birth rather than citizenship. Whilst citizenship characterizes the foreign population, the concept of foreign-born better captures the decision to emigrate ${ }^{10}$. Usually, the number of foreign-born is much higher than the number of foreign citizens (twice as large in countries such as Hungary, the Netherlands, and Sweden) ${ }^{11}$. Another reason is that the concept of country of birth is time invariant (contrary to citizenship which changes with naturalization) and independent of the changes in policies regarding naturalization. The OECD statistics report that 14.4 million of foreign born individuals were naturalized between 1991 and 2000. Countries with a particularly high number of acquisitions of citizenship are the US (5.6 million), Germany (2.2 million), Canada (1.6 million), and Australia and France (1.1 million). Despite the fact that they are partially reported in traditional statistics (OECD, 2002), the number of foreign-born can be obtained for a large majority of OECD countries. In a limited number of cases, the national census only gives immigrants' citizenship (Germany, Italy, Greece, Japan and Korea). As it will appear in Table 2, 88.3 percent of working-aged immigrants can be characterized in term of country of birth in 2000 (11.7 percent in term of citizenship). Contrary to common belief, data availability is not significantly different in 1990, even among European states. We obtain information about country of birth for 88.0 percent of working-aged immigrants in 1990 (12.0 in term of citizenship).

- It is worth noting that the concept of foreign born is not fully homogeneous across OECD countries. As in many OECD countries, our main criterion relies on both country of birth and citizenship at birth: we define foreign born as an individual born abroad with foreign

estimation is unaffected if the shares are constant across countries or if the difference between the share $m_{i}$ in country $\mathrm{i}$ and $m_{j}$ in country $\mathrm{j}$ is equal to a random (white noise) variable, $\forall i, j$, i.e., for $m_{i}=m_{A}+\varepsilon_{i}$, with $m_{A}$ is the average share, $\varepsilon_{i}$ is an "iid" random (white noise) variable.

${ }^{10}$ In some receiving countries such as Germany, immigrants' children (i.e. the second generation) usually keep their foreign citizenship.

${ }^{11}$ By contrast, in other OECD countries with a restricted access to nationality (such as Japan, Korea, and Switzerland), the foreign population is important (about 20 percent in Switzerland). 
citizenship at birth. For example, the U.S Census Bureau considers as natives persons born in the US (as well as in Puerto Rico or U.S. Island areas), or born abroad from a U.S. citizen parent $^{12}$. Other residents are considered foreign born. France and Denmark use a imilar concept. Statistics Netherlands defines first-generation immigrants as persons who are born abroad and have at least one parent who is also born abroad (Alders M., 2001). However, in a couple of countries (Australia, New Zealand, and Belgium), the " foreign born" concept used by the Statistics Institute essentially means " overseas-born" , i.e. an individual simply born abroad. Whilst it is impossible to use a fully comparable concept of immigration, we have tried to maximize the homogeneity of our data sources. It is worth noting that our definition clearly excludes the second generation of immigrants. A couple of countries offer a more detailed picture of immigration, distinguishing the foreign born and those with foreign background (basically immigrants' descendants born locally from one of two foreign-born parents) ${ }^{13}$.

- As discussed above, emigration rates are provided for 195 territories in 2000 (191 UN member states, Vatican, Palestine, Hong Kong, Taiwan, Macao minus one Korean country). The world configuration has changed between 1990 and 2000. Czechoslovakia seceded into the Czech Republic and the Slovak Republic, the ex-USSR seceded into 15 countries (7 on the European continent and 8 on the Asian continent), Ex-Yugoslavia seceded into 5 countries, Eritrea and East Timor emerged as a independent countries in 1993 and 2002. On the contrary, Germany and Yemen were unified. Consequently, we distinguish 174 countries in 1990 (the ex-USSR replaces 15 countries, ex-Yugoslavia replaces 5 countries, ex-Czechoslovakia replaces 2 countries). For homogeneity reasons, we aggregated East and West Germany as well as the Democratic Republic and the Republic Yemen in 1990. In 1990, the ex-USSR totally belongs to the European area ${ }^{14}$.

- A related issue concerns the dependent territories. Each dependent territory is linked to a nation. Individuals born in these territories have the unrestricted right to move to and to live in the nation. We naturally consider them as natives of the sovereign nation. Once the concept of foreign born is chosen, it means that they should not be considered as immigrants if they move to the sovereign state (internal migration). They should only be considered as immigrants if they move to another independent state (external migration).

\footnotetext{
${ }^{12}$ See Malone et al. (2003) for more details.

${ }^{13}$ Data by foreign background are provided in the Netherlands, France and Scandinavian countries. See Alders (2001) for the Netherlands or Ostby (2002) for Norway.
} 
This criterion is especially important for U.S. dependent territories (such as Puerto Rico and the US Island Areas such as Guam, etc.), UK overseas territories (Bermuda, Anguilla, etc.), French dependent territories (such as Guadalupe, Reunion, etc.), Denmark (Greeland and Faroe Islands, etc.) or around Australia and New-Zealand (Cook Islands, Niue, Tokelau, etc.).

- For example, in accordance with the US Census Bureau definition, we consider that one million of Puerto Ricans living in the United States are U.S. natives but not immigrants. This considerably reduces the total stock of Puerto Rican emigrants. We have computed on the same basis the emigration stock for the other dependent territories, except for Taiwan, Hong Kong and Macao which are assimilated to independent countries. Then, given the small numbers obtained, we have eliminated Northern Mariana Islands and Western Sahara (a disputed rather than dependent territory) and have summed up Jersey and Guernsey (forming Channel Islands). Stock data for 33 dependent territories are provided in Table A.3.

- As the second step of our analysis consists in comparing the numbers of emigrants and residents by educational attainment, we have to consider homogeneous groups. Working on the working-aged population (aged 25 and over) maximizes the comparability of the immigration population with data on educational attainment in source countries. It also excludes a large number of students who temporarily emigrate to complete their education. We cannot control for graduate students aged 25 and over completing their schooling $^{15}$. As it will appear in Table 1 the age group is slightly different in a limited number of countries.

Building an aggregate measure of emigration per educational attainment requires a rule for sharing the unknown values. At the OECD level, the number of migrants whose educational attainment is not described amounts to 1.287 million, i.e. 2.2 percent of the total stock. Two reasonable rules could be considered: either unknown values can be distributed in the same way as the known values or they can be assimilated as unskilled. We combine both rules depending on the information available in the receiving country. For receiving countries

\footnotetext{
${ }^{14}$ Note that aggregating appropriated stock data would allow computation of emigration rates for ex-Yugoslavia, the ex-USSR and ex-Czechoslovakia in 2000.

${ }^{15}$ Carrington and Detragiache (1998) used data from the Institute of International Education to estimate the number of graduate students completing their schooling in the United States. We consider that some of these students aged 25 and over receive grants and can be considered as workers (researchers).
} 
where information about immigrants' education is available, we assimilate the unknowns to unskilled workers ${ }^{16}$.

For example, Australian immigrants who did not mention their educational attainment are considered unskilled. In receiving countries where no information about skill is available, we transpose the skill distribution observed in the rest of the OECD area or in the neighboring region. For example, if we have no information about the skill structure of immigrants to Iceland, Algerian emigrants to Iceland are assumed to be distributed in the same way as Algerian emigrants to the rest of the Scandinavian countries. The assumptions will be discussed below.

Formally, the stocks of emigrants of skill $s$ from country $j$ at time $t\left(M_{t, s}^{\bullet j}\right)$ are obtained as follows:

(1)

$$
\left\{\begin{array}{l}
M_{t, h}^{\bullet j}=\sum_{i} M_{t, h}^{i, j}+\sum_{i} M_{t, u}^{i, j} \cdot \Psi_{t}^{i} \cdot \frac{\sum_{i} M_{t, h}^{i, j}}{\sum_{i} \sum_{s} M_{t, s}^{i, j}} \\
M_{t, m}^{\bullet j}=\sum_{i} M_{t, m}^{i, j}+\sum_{i} M_{t, u}^{i, j} \cdot \Psi_{t}^{i} \cdot \frac{\sum_{i} M_{t, m}^{i, j}}{\sum_{i} \sum_{s} M_{t, s}^{i, j}} \\
M_{t, l}^{\bullet}=\sum_{i} M_{t, l}^{i, j}+\sum_{i} M_{t, u}^{i, j} \cdot \Psi_{t}^{i} \cdot \frac{\sum_{i} M_{t, m}^{i, j}}{\sum_{i} \sum_{s} M_{t, s}^{i, j}}+\sum_{i} M_{t, u}^{i, j} \cdot\left(1-\Psi_{t}^{i}\right)
\end{array}\right.
$$

where $\Psi_{t}^{i}$ is a (time and country dependent) binary variable equal to one if there is no data on the immigrants' skill in country $i$, and equal to zero otherwise. Table 1 describes the data sources.

\footnotetext{
${ }^{16}$ Country specific data by occupation reveal that the occupational structure of those with unknown education is very similar to the structure of low-skilled workers (and strongly different from that of high-skilled workers). See Debuisson et al. (2004) on Belgian data.
} 
Table 1. Data sources

\begin{tabular}{|c|c|c|c|c|}
\hline & \multicolumn{2}{|c|}{$1990(+)$} & \multicolumn{2}{|c|}{$2000(+)$} \\
\hline Country - Age group & Origin & Education & Origin & Education \\
\hline Australia (25+) & Census (\#) & Census (\#) & Census (\#) & Census (\#) \\
\hline Austria $(25+)$ & Census & Census & Census & Census \\
\hline Belgium (25+) & Census & Census & $\begin{array}{c}\text { Improved EC } \\
(* *)\end{array}$ & LFS \\
\hline Canada $(25+)$ & Census (\#) & Census (\#) & Census (\#) & Census (\#) \\
\hline Czech Rep (25+) & Census (\#) & - & Census (\#) & Census (\#) \\
\hline Denmark (25+) & Register & Register & Register & Register \\
\hline Finland (25+) & Register & Register & Register & Register \\
\hline France $(25+)$ & Census (\#) & Census (\#) & Census (\#) & Census (\#) \\
\hline Germany (25-65) & $\begin{array}{l}\text { Microcensuz* } \\
\text { (Cit) }\end{array}$ & $\begin{array}{l}\text { Microcensuz* } \\
\text { (Cit) }\end{array}$ & $\begin{array}{l}\text { Microcensuz* } \\
\text { (Cit) }\end{array}$ & $\begin{array}{l}\text { Microcensuz* } \\
\text { (Cit) }\end{array}$ \\
\hline Greece $(25+)$ & EC (Cit) & LFS (Cit.) & EC (Cit) & LFS (Cit.) \\
\hline Hungary (All;25+) & EC (Cit) & - & Census & Census \\
\hline Iceland (All) & Register & - & Register & - \\
\hline Ireland (25+) & Census & Census & Census & Census \\
\hline Italy $(25+)$ & EC (Cit) & - & Census (Cit) & Census (Cit) \\
\hline Japan (All/25+) & Register (Cit) & - & Census (Cit) & - \\
\hline Korea (All) & Register (Cit) & - & Register (Cit) & - \\
\hline Luxemburg (25+) & Census (\#) & Census (\#) & Census (\#) & Census (\#) \\
\hline Mexico (25+) & Ipums (+) 10\% & Ipums (+) 10\% & Ipums (+) 10.6\% & Ipums (+) 10.6\% \\
\hline Netherland (All) & Census* & Census* & Census* & Census* \\
\hline New Zealand (15+) & Census & Census & Census & Census \\
\hline Norway (25+) & Register & Register & Register & Register \\
\hline Poland (13+) & Census (\#) & - & Census (\#) & Census (\#) \\
\hline Portugal (25+) & Census & LFS & Census & LFS \\
\hline Slovak Rep (25+) & See Czech Rep & See Czech Rep & Census (\#) & Census (\#) \\
\hline Spain $(25+)$ & Census & Census & Census & Census \\
\hline Sweden (25+) & Census & Census & Census & Census \\
\hline Switzerland (18+) & Census (\#) & Census (\#) & Census (\#) & Census (\#) \\
\hline Turkey (15+) & Census (\#) & Census (\#) & Census (\#) & Census (\#) \\
\hline $\begin{array}{l}\text { United Kingdom } \\
(15+)\end{array}$ & Census* & Census* & Census* & Census* \\
\hline United States $(25+)$ & Ipums (+) 5\% & Ipums(+) 5\% & Census 100\%* & Census 100\%* \\
\hline
\end{tabular}

Notes: EC = European Council (register data); LFS = Labor Force Survey; $\left(^{*}\right)=$ limited level of detail.

$(* *)$ European Council data corrected by the country specific "foreign born/foreign citizen" ratio in Census 1991.

(+) Year around 1990 and 2000 (for example, the Australian censuses refer to 1991 and 2001)

(\#) Data available in Release 1.0.

(+) See Ruggles et al. (2004) on the US and Sobek et al. (2002) on the Mexican sample.

In 2000, we use census, microcensus and register data for 29 countries. European Council data are used in the case of Greece. Information on the country of birth are available for the large majority of countries, representing 88.3 percent of the OECD immigration stock. 
Information on citizenship are used for the other countries (Germany, Italy, Greece, Japan, and Korea). The educational structure can be obtained in 24 countries and can be estimated in 3 additional countries on the basis of the European Labor Force Survey (Belgium, Greece, and Portugal). As will appear in Table 2, data built on the Labor Force Survey only represent 2 percent of the OECD migration stock in 2000 (0.7 percent in 1990). In the 3 remaining countries, the educational structure is extrapolated on the basis of the Scandinavian countries (for Iceland) or the rest of the OECD (for Japan and Korea). In 1990, European Council data must be used for Hungary and Italy. These data are based on the concept of citizenship. Compared to 2000, educational attainment is not available in Italy, the Czech Republic and Hungary. The Italian educational structure is based on the rest of the EU15. For the other two countries, we use proportions computed from the rest of Europe. On the contrary, the Belgian 1991 Census is available and provides complete data by country of birth and educational attainment.

\subsection{Emigration rates}

In the spirit of Carrington and Detragiache (1998) and Adams (2003), our second step consists in comparing the emigration stocks to the total number of people born in the source country and belonging to the same educational category. Calculating the brain drain as a proportion of the total educated labor force is a better strategy to evaluate the pressure imposed on the local labor market. It is indeed obvious that the pressure exerted by 1,037,000 Indian skilled emigrants (4.3\% of the educated total labor force) is less important than the pressure exerted by 16,000 skilled emigrants from Grenada ( $85 \%$ of the educated labor force).

Denote $N_{t, s}^{j}$ as the stock of individuals aged 25+, of skill $s$, living in country $j$, at time $t$, we define the emigration rates by

(2) $\quad m_{t, s}^{j}=\frac{M_{t, s}^{j}}{N_{t, s}^{j}+M_{t, s}^{j}}$ 
In particular, $m_{t, h}^{j}$ provides information about the intensity of the brain drain in the source country $j$. It measures the fraction of skilled agents born in country $j$ and living in (other) OECD countries ${ }^{17}$.

This step requires using data on the size and the skill structure of the working-aged population in the countries of origin. Population data by age are provided by the United Nations ${ }^{18}$. We focus on the population aged 25 and more. Data are missing for a couple of countries but can be estimated using the CIA world factbook ${ }^{19}$. Population data are split across educational groups using international human capital indicators. Several sources based on attainment and/or enrollment variables can be found in the literature. These data sets suffer from two important limitations. First, data sets published in the nineties reveal a number of suspicious features and inconsistencies ${ }^{20}$. Second, given the variety of educational systems around the world, they are subject to serious comparability problems.

Three major competing data sets are available: Barro and Lee (2000), Cohen and Soto (2001) and De La Fuente and Domenech (2002). The first two sets depict the educational structure in both developed and developing countries. The latter only focuses on 21 OECD countries. Statistical comparisons between these sets reveal that the highest signal/noise ratio is obtained in De La Fuente and Domenech. These tests are conducted in OECD countries. Regarding developing countries, Cohen and Soto's set outperforms Barro and Lee's set in growth regressions. However, Cohen and Soto's data for Africa clearly underestimate official statistics. According to the South African 1996 census, the share of educated individuals amounts to 7.2 percent. Cohen and Soto report 3 percent (Barro and Lee report 6.9 percent). The Kenyan 1999 census gives 2 percent whilst Cohen and Soto report 0.9 percent (1.2 for Barro and Lee).

Generally speaking, the Cohen and Soto data set predicts extremely low levels of human capital for African countries $^{21}$ (the share of tertiary educated is lower than 1 percent in a large number of African countries) and a couple of other non-OECD countries ${ }^{22}$. The Barro and Lee

\footnotetext{
${ }^{17}$ For some countries, immigrants often travel back and forth between their new and old countries (e.g. Mexico). They are likely to be counted as still being residents in their home country. For that reason, Carrington and Detragiache (1998) provide an upper bound $(\mathrm{m}=\mathrm{M} / \mathrm{N})$ and a lower bound $(\mathrm{m}=\mathrm{M} /(\mathrm{N}+\mathrm{M}))$. Since the upper bound is not interpretable for a large number of countries (higher than one), we only report the lower bound.

${ }^{18}$ See http://esa.un.org/unpp.

${ }^{19}$ See http://www.cia.gov/cia/publications/factbook.

20 This partly explains why human capital did not prove to be significant or distort the " good sign" in growth regressions.

${ }^{21}$ For this reason, Cohen and Soto (2001) exclude African countries from their growth regressions.

${ }^{22}$ In Cyprus, the 2001 census gives 22\%, compared with 4.6\% in Cohen and Soto (17.1\% in Barro and Lee).
} 
estimates seem closer to the African official statistics. As the brain drain is particularly important in African countries, Barro and Lee indicators are preferable. Consequently, data for $N_{t, s}^{j}$ are taken from De La Fuente and Domenech (2002) for OECD countries and from Barro and Lee (2000) for non-OECD countries. For countries where Barro and Lee measures are missing (about 70 countries in 2000), we transpose the skill sharing of the neighboring country with the closest human development index regarding education. This method gives good approximations of the brain drain rate, broadly consistent with anecdotal evidence.

\subsection{Changes between 1990 and 2000}

The number of skilled migrants has drastically increased in recent decades. This is partly explained by the many "quality-selective” policies that were introduced in OECD countries in the 1980s and 1990s. The stock of high-skilled immigrants residing in the OECD increased by 70\% between 1990 and 2000, while that of unskilled immigrants increased by only 30\% during the same period (Docquier and Marfouk, 2006). However, this rapid increase in the stock of skilled migrants does not imply that the rate of skilled migration increased at a similar rate because the last decade was also characterized by a sharp rise in the educational attainment in sending countries. Consequently, as shown in the Docquier-Marfouk's database, the brain drain only experienced a minor change between 1990 and 2000 (from 5.0 to 5.4 percent).

\section{RESULTS FOR SMALL STATES}

Table 2 presents information on skilled and average emigration rates, and on the schooling gap (defined below), for 1990, the period 1990-2000, and for 2000, with focus on small states. The data are provided for small states as a whole, and grouped according to population size, region and income, and for small developing island states. The emigration rates are also provided for other country groupings, including those with somewhat larger population, the world, and for high-income countries and developing countries as a whole.

Table 2 presents a number of interesting findings. We start with those associated with the skilled emigration rate (first column). 


\subsection{Skilled Emigration Rate}

First, the skilled emigration rate or brain drain shows a dramatic difference in the extent of the brain drain -- or skilled migration rate -- for small states relative to that for developing countries as a whole. In 1990, the small states' brain drain was equal to $50 \%$ and that for developing countries as a whole was $7.8 \%$ or less than $16 \%$ of the former. Similarly, the small states' brain drain in 1990-2000 was 36.1\% and that for developing countries as a whole was $7.0 \%$ or less than $20 \%$ of the former. Finally, the small states' brain drain was equal to $43.2 \%$ in 2000 and that for developing countries as a whole was $7.4 \%$ or less than $18 \%$ of the former.

Second, the brain drain for small states is even larger when compared with the world as a whole or with high-income countries. The brain drain in high-income countries was $3.8 \%$ or $7.6 \%$ of that of the small states in 1990 , and $3.5 \%$ or $8.1 \%$ of the small states' brain drain in 2000. As for the world average, the corresponding numbers are $5.2 \%$ in 1990 and $5.3 \%$ in 2000 , or $10.4 \%$ and $12.3 \%$ of the small states’ brain drain, respectively.

Third, though the small states' brain drain has been extremely large in recent decades (with the 1990 figure reflecting preceding brain drain episodes), it has been declining. The decline from $50 \%$ in 1990 to $43.2 \%$ in 2000 amounts to a $13.6 \%$ reduction in a decade. This is a major change, considering that these figures relate to stocks.

Fourth, Table 2 also presents a disaggregation of the small states into three groups according to population size $\mathrm{P}$ (in millions). These are referred to here as Group 1 (P $<.5)$, Group 2 (.5 $<$ $\mathrm{P}<1)$, and Group $3(1<\mathrm{P}<1.5)$. The brain drain in Groups 1 and 2 was 46\% in 1990 and $69 \%$ in Group 3. The latter was thus 50\% larger than the former two. The opposite holds in 2000, with the brain drain in Group 3 (40.9\%) lower than that in Group 1 (41.7\%) and in Group 2 (47.2\%). The $40 \%$ reduction in the brain drain of Group 3 from $68.9 \%$ in 1990 to $40.9 \%$ in 2000 is due to a $60 \%$ decline in the period $1990-2000$ (from $68.9 \%$ to $28.3 \%$ ). Thus, the decrease in small states' brain drain from $50 \%$ to $43.2 \%$ was essentially due the decline in Group 3. ${ }^{23}$

Fifth, Table 2 presents two other groups according to population, referred to here as Group 4 with $1.5<\mathrm{P}<3$, and Group 5 with $3<\mathrm{P}<4$. The brain drain in Group 4 was half of that in small states in 1990 (25\% versus 50\%) and about half in 2000 (20.9\% versus 43.2\%), while that in Group 5 was $41.4 \%$ of that in small states in 1990 (20.7\% versus 50\%) and $42.8 \%$ in

\footnotetext{
${ }^{23}$ Group 2 experienced a 3\% brain drain increase from 1990 to 2000 (from 45.8 to $47.2 \%$ ) and Group 1 experienced a $9 \%$ decrease (from 46 to $41.7 \%$ ).
} 
2000. In other words, the size of the brain drain exhibited a negative relationship with respect to population size. It was greater for small states as a whole, smaller by about half in Group 4, and again smaller (by close to 60\%) in Group 5.

Sixth, the brain drain for small island developing states was similar to that for small states as a whole. It is $10 \%$ smaller that the latter in 1990 (45\% versus 50\%) and 2\% smaller in 2000 (42.4\% versus $43.2 \%)$.

Seventh, Table 2 also presents a disaggregation of small states by region and income. The brain drain in 1990 was largest in Latin America and the Caribbean (75.4\%) and in East Asia and the Pacific (74.2\%), smaller in Sub-Saharan Africa (43.3\%) and smallest in high-income countries (24.9\%). The figures are similar in 2000, except for East Asia and the Pacific where the brain drain declined dramatically, from $74.2 \%$ in 1990 to $50.8 \%$ in 2000 or by over 30\%, due to a huge reduction (by 56\%) in the brain drain in 1990-2000 compared to 1990.

\subsection{Schooling Gap}

Table 2 also provides information on the "Schooling gap," which we now define. First, in order to simplify notation, equation (2) is reproduced here as equation (2') where the time subscript $t$ and the country superscript $j$ have been deleted. Then, the skilled emigration rate or brain drain $\left(m_{h}\right)$ is given by

(2') $\quad m_{h}=\frac{M_{h}}{N_{h}+M_{h}}$,

where $M_{h}$ is the stock of skilled migrants aged 25+, and $N_{h}$ is the stock of skilled individuals aged 25+ living in their country of birth.

The average migration rate is

(3) $\quad m=\frac{M}{N+M}$,

where $M$ is the stock of migrants aged 25+, and $N$ is the population of individuals aged 25+ living in their country of birth. The schooling gap SG is defined as the share of the skilled in the migrant population divided by the share of the skilled in the total population, i.e.: 
(4) $S G=\frac{M_{h}}{M} /\left(\frac{N_{h}+M_{h}}{N+M}\right)=\frac{M_{h}}{N_{h}+M_{h}} / \frac{M}{M+N}=\frac{m_{h}}{m}$.

Thus, the schooling gap - shown in the third column of Table 3 for each period -- can also be interpreted as the skilled migration rate $m_{h}$ divided by the average migration rate $m$, i.e., as $m_{h} / m$. Below are a few results from Table 2.

First, the schooling gap for small states as a whole was 3.34 in 1990. It was much higher in Group 3, the largest of the small states groups $(1<\mathrm{P}<1.5)$, with a value of 7.65 or some $130 \%$ greater than that for small states as a whole. The schooling gap was about the same for Group 2 as for small states as a whole (3.21 versus 3.34 or $4 \%$ less), and was 2.27 for Group 1 or $32 \%$ smaller than that for small states as a whole. Thus, the schooling gap within the small states groups was inversely related to the population size, and the same held for 2000.

Second, the schooling gap for small states was very close to the world average both in 1990 and 2000. It was greater than for high income countries (by some 165\% in 1990 and $120 \%$ in 2000) and was smaller than for developing countries as a whole (by over 20\% in 1990 and by over $30 \%$ in 2000).

Third, the small states schooling gap fell from 3.34 in 1990 to 2.81 in 2000 or by some $16 \%$, about the same percentage decline as that for the brain drain, the reason being that the average emigration rate remained about the same (changing by only 2\%, from 15.0 to $15.3 \%$ ). It also fell in Groups 1, 2 and 3, with that of Group 3 exhibiting a dramatic decline from 7.65 in 1990 to 4.20 in 2000 or by $45 \%$. The latter was the main cause that the schooling gap declined for small states as a whole.

Fourth, the 1990 schooling gap was extremely high in Sub-Saharan Africa at 8.31, was high for East Asia and the Pacific at 4.38, and was much lower for Latin America and the Caribbean at 2.52, with the lowest for high-income countries at 2.07. These schooling gaps were, respectively, $150 \%$ greater, over $30 \%$ greater, $25 \%$ smaller and $38 \%$ smaller than that for small states as a whole. The schooling gaps fell for all three developing regions, with their order unchanged, except for the high income group where it increased some. Importantly, it fell significantly in Sub-Saharan Africa, from 8.31 to 6.95 or by $16.4 \%$, slightly more than the $15.8 \%$ decrease for small states as a whole.

Fifth, the decline in the schooling gap was about twice as large for developing countries as a whole as for the small states, with a reduction from 7.18 in 1990 to 4.92 in 2000 or by $31.5 \%$, 
compared to a reduction of $15.8 \%$ for the small states. The greater reduction for the former was certainly not due to the reduction in the brain drain which was in fact greater for small states (13.6\% versus $4.4 \%)$. Rather, it was due to a significant increase in the average emigration rate from 1.1 to $1.5 \%$ or by $36 \%$, compared to a $2 \%$ increase for small states.

Sixth, the schooling gap for high-income countries remained constant between 1990 and 2000 at about 1.26 and fell for the world as a whole from 3.316 to 2.993 or by $8.8 \%$. The world average schooling gap was equal to that for small states in 1990 and some 6\% greater in 2000.

Seventh, note that the reduction in the schooling gap should be considered a benefit for source countries in the sense that the difference between the skill intensity of emigration $M_{h} / M$ and that of the population as a whole $\left(N_{h}+M_{h}\right) /(N+M)$ decreases (see equation 4$)$. The reason is that the brain drain should be less harmful for source countries because of their relatively greater supply, either because of a reduction in the share of skilled labor in migration or because of an increase in the share of skilled labor in the population (including the migrants themselves). This was the case for all country groupings except for high-income small states and high-income countries as a whole.

Eighth, skilled immigrants are defined as foreign-born workers with university or postsecondary training living abroad. This definition does not distinguish between education acquired in the home or in the host country. Rosenzweig (2005) shows on the basis of US survey data that migration of children represent an important fraction of total migration for certain countries. On average, 18 percent of permanent resident aliens immigrated to the US before eighteen and over twenty 25 immigrated before twenty. Among these, some are highlyskilled today, having most likely acquired a higher education after coming to the US. 
Table 2. Emigration rates by country group

\begin{tabular}{|c|c|c|c|c|c|c|c|c|c|c|}
\hline & \multicolumn{4}{|c|}{2000} & \multicolumn{3}{|c|}{1990} & \multicolumn{3}{|c|}{$2000 / 1990$} \\
\hline & $\mathbf{N b}$ & $\begin{array}{c}\text { Skilled } \\
\text { emigration } \\
\text { rate }\end{array}$ & $\begin{array}{c}\text { Average } \\
\text { emigration } \\
\text { rate }\end{array}$ & $\begin{array}{l}\text { Schooling } \\
\text { gap }\end{array}$ & $\begin{array}{c}\text { Skilled } \\
\text { emigration } \\
\text { rate }\end{array}$ & $\begin{array}{c}\text { Average } \\
\text { emigration } \\
\text { rate }\end{array}$ & $\begin{array}{l}\text { Schooling } \\
\text { gap }\end{array}$ & $\begin{array}{c}\text { Skilled } \\
\text { emigration } \\
\text { rate }\end{array}$ & $\begin{array}{c}\text { Average } \\
\text { emigration } \\
\text { rate }\end{array}$ & $\begin{array}{l}\text { Schooling } \\
\text { gap }\end{array}$ \\
\hline $\begin{array}{l}\text { Small States (pop }<1.5 \\
\text { million) } \\
\text { by population size }\end{array}$ & 46 & $43.2 \%$ & $15.3 \%$ & 2.812 & $50.0 \%$ & $15.0 \%$ & 3.339 & $36.1 \%$ & $16.2 \%$ & 2.228 \\
\hline Population from 0 to 0.5 million & 32 & $41.7 \%$ & $21.0 \%$ & 1.984 & $46.0 \%$ & $20.2 \%$ & 2.274 & $35.9 \%$ & $24.1 \%$ & 1.491 \\
\hline Population from 0.5 to 1 million & 8 & $47.2 \%$ & $15.7 \%$ & 3.007 & $45.8 \%$ & $14.3 \%$ & 3.213 & $49.3 \%$ & $19.0 \%$ & 2.591 \\
\hline $\begin{array}{c}\text { Population from } 1 \text { to } 1.5 \text { million } \\
\text { by region / income }\end{array}$ & 6 & $40.9 \%$ & $9.8 \%$ & 4.198 & $68.9 \%$ & $9.0 \%$ & 7.646 & $28.3 \%$ & $10.8 \%$ & 2.617 \\
\hline East Asia and Pacific & 12 & $50.8 \%$ & $17.0 \%$ & 2.986 & $74.2 \%$ & $16.9 \%$ & 4.381 & $32.6 \%$ & $17.2 \%$ & 1.900 \\
\hline Latin America and Caribbean & 10 & $74.9 \%$ & $35.0 \%$ & 2.143 & $75.4 \%$ & $30.0 \%$ & 2.515 & $74.3 \%$ & $51.4 \%$ & 1.446 \\
\hline Sub-Saharan Africa & 10 & $41.7 \%$ & $6.0 \%$ & 6.947 & $43.3 \%$ & $5.2 \%$ & 8.307 & $39.6 \%$ & $8.5 \%$ & 4.649 \\
\hline High-income countries & 12 & $23.0 \%$ & $10.7 \%$ & 2.144 & $24.9 \%$ & $12.0 \%$ & 2.073 & $19.4 \%$ & $5.3 \%$ & 3.675 \\
\hline Other Groups of Interest & & & & & & & & & & \\
\hline Small Islands Developing States & 37 & $42.4 \%$ & $13.8 \%$ & 3.073 & $45.0 \%$ & $11.8 \%$ & 3.808 & $39.4 \%$ & $20.0 \%$ & 1.965 \\
\hline Population from 1.5 to 3 million & 15 & $20.9 \%$ & $7.1 \%$ & 2.960 & $25.0 \%$ & $5.7 \%$ & 4.366 & $18.5 \%$ & $8.7 \%$ & 2.125 \\
\hline Population from 3 to 4 million & 13 & $18.5 \%$ & $10.0 \%$ & 1.849 & $20.7 \%$ & $11.1 \%$ & 1.874 & $16.7 \%$ & $8.8 \%$ & 1.904 \\
\hline World average & 192 & $5.3 \%$ & $1.8 \%$ & 2.993 & $5.2 \%$ & $1.6 \%$ & 3.316 & $5.4 \%$ & $2.4 \%$ & 2.309 \\
\hline Total high-income countries & 41 & $3.5 \%$ & $2.8 \%$ & 1.264 & $3.8 \%$ & $3.0 \%$ & 1.258 & $2.9 \%$ & $1.2 \%$ & 2.529 \\
\hline Total developing countries & 151 & $7.4 \%$ & $1.5 \%$ & 4.916 & $7.8 \%$ & $1.1 \%$ & 7.182 & $7.0 \%$ & $2.5 \%$ & 2.831 \\
\hline
\end{tabular}

Skilled emigration rates and average emigration rates are defined by equation (2).

Schooling gap $=$ Skilled emigration rate $/$ Average emigration rate

Source : Docquier and Marfouk (2006) 


\section{ALTERNATIVE MEASURES CONTROLLING FOR AGE OF ENTRY}

The previous data on international skilled migration define skilled immigrants as foreign-born workers with university or post-secondary training. However, this definition does not account for whether education has been acquired in the home or in the host country and thus leads to a potential over-estimation of the intensity of the brain drain as well as to possible spurious cross-country variation in skilled emigration rates.

As shown by Rosenzweig (2005) on the basis of US survey data, children migration can represent an important fraction of total immigration for certain countries as over 18 percent of permanent resident aliens immigrated to the US before age 18, and over 25 percent immigrated before age 20. Among those who arrived before age 18 or 20, some are highlyskilled today, having most likely acquired education once in the US. Should we include them as part of the "brain drain"?

As explained, existing brain drain data sets are built according to a broad definition in that they include all foreign-born workers with tertiary schooling; for example, Mexican-born individuals who arrived in the US at age 5 or 10 and then graduated from US high-education institutions later on are counted as highly-skilled Mexican immigrants. This can be seen as providing an upper bound to brain drain estimates.

In contrast, it has been suggested that only people with home-country higher education should be considered as skilled immigrants (Rosenzweig 2005). This must be considered as a lowerbound measure of the brain drain. Indeed, except for those arrived at very young age, most of the immigrants who then acquired host country tertiary education arrived with some level of home country pre-tertiary schooling. In addition, some of them would still have engaged in higher education in the home country in the absence of emigration prospects.

In this section, we use immigrants' age of entry as a proxy for where education has been acquired. Data on age of entry are available from a subset of receiving countries which together represent more than three-quarters of total skilled immigration to the OECD. Using these data and a simple gravity model, we estimate the age-of-entry structure of skilled immigration to the other OECD countries. This allows us to propose alternative measures of the brain drain by defining skilled immigrants as those who left their home country after age 12, 18 or 22, and to do so for both 1990 and 2000. These corrected skilled emigration rates, which can be seen as intermediate bounds to the brain drain estimates, are by construction 
lower than those computed without age-of-entry restrictions by Docquier and Marfouk (2006), which we take as our upper-bound brain drain measure.

\subsection{Methdology}

To estimate the structure of immigration by age of entry, we collect census and register data in a sample of countries where such information is available: the US 1990 and 2000 censuses, the Canadian 1991 and 2001 censuses, the French 1999 census, the Australian 1991 and 2001 censuses, the New-Zealand 1991 and 2001 censuses, the Danish 2000 register, the Greek 2001 census and the Belgian 1991 census. Together, the countries sampled represent 77 percent of total skilled immigration to the OECD area. The sample is representative of the OECD in that it includes countries with different demographic sizes, regional locations, development levels and immigration policy and tradition.

We thus have bilateral information on immigrants' origin, age, education level and age of entry from 12 host countries' censuses for 192 sending countries. These 2304 observations allow us to compute the proportion of immigrants arrived before ages 12, 18 and 22 in the total stocks of immigrants aged 25+ estimated by Docquier and Marfouk (2006). Eliminating zeros and a few suspicious observations, we end up with 1580 observations for each age threshold.

Table 3 gives descriptive statistics on the estimated proportions of adult immigrants who arrived before age $\mathrm{J}(\mathrm{J}=12,18$ and 22$)$. The average shares vary across receiving countries (not shown). On the whole, the average shares are 85.7\%, 78.2\% and 69.1\% for immigrants arrived before age 12, 18 or 22. They are usually higher for Belgium, Denmark and Greece. The lowest shares are observed in Australia, New Zealand and the United States. Canada and France are not far from the average distribution.

Obviously, an approach based on Census data is not perfect. As explained by Rosenzweig (2005, p. 9), "information on entry year ... is based on answers to an ambiguous question - in the US Census the question is "When did you first come to stay?" ” Immigrants might answer this question by providing the date when they received a permanent immigrant visa, not the date when they first came to the US, at which time they might not have intended to or been able to stay. Only surveys based on a comprehensive migration history would provide precise data about the location in which schooling was acquired. 
However, the Census is the only representative source of data available in many countries. In addition, extrapolating the entry age structure from surveys (such as NIS - 4\\% of immigrants - or NSIP - a sample of 150,000 persons out of more than 25,000,000 adult immigrants - for the US) can be misleading. The number of observations can be very small for countries with few emigrants; this is typically the case of small countries which, on the other hand, are precisely the ones most affected by the brain drain in relative terms.

\subsection{Results for small states}

Table 3 presents the results for the brain drain from small states for all those who migrated, irrespective of their age (as in Table 2), for those who migrated before age 12, 18 and 22, and also the ratio of the latter to all those who migrated $(22+/ 0+)$. Focusing on that ratio, we see for 2000 that it is equal to $70.1 \%$ for small states as a whole, with little variation across the three population groups (Groups 1 to 3), and about the same as that for developing as a whole. It is about $8 \%$ smaller for high-income countries and $2 \%$ smaller for the world average.

The ratio declined from 1990 to 2000 for small states as a whole (from 74.0 to $70.1 \%$ ) as well as for all small states groups (with the major decline for the largest group and for East Asia and Pacific), implying that a larger share of migrants obtained their degrees at home. On the other hand, the ratio increased for all other country groups.

Table 4 shows the brain drain by small state for the various age-of-entry groups. The correlation between the first group (BD 0+) and the last group (BD 22+), with identical ranking of the top six countries (Guyana, Grenada, Saint Vincent and the Grenadines, Trinidad and Tobago, Saint Kitts and Nevis, and Samoa), with 9 of the top 10 countries for BD 22+ also in the top 10 for BD 0+, and with the same top 20 countries in both groups. 
Table 3. Adjusted brain drain by country group (1990 and 2000)

\begin{tabular}{|c|c|c|c|c|c|c|c|c|c|c|c|}
\hline & & & 2000 & & & & & 1990 & & & \\
\hline & Nb & BD 0+ & BD 12+ & BD 18+ & BD 22+ & $\begin{array}{c}\text { Ratio } \\
22+/ 0+\end{array}$ & BD 0+ & BD 12+ & BD 18+ & BD 22+ & $\begin{array}{c}\text { Ratio } \\
22+/ 0+\end{array}$ \\
\hline $\begin{array}{l}\text { Small States (pop }<1.5 \text { million) } \\
\text { by population size }\end{array}$ & 46 & $43.2 \%$ & $39.4 \%$ & $35.4 \%$ & $30.2 \%$ & $70.1 \%$ & $50.0 \%$ & $46.3 \%$ & $42.3 \%$ & $37.0 \%$ & $74.0 \%$ \\
\hline Population from 0 to 0.5 million & 32 & $41.7 \%$ & $38.0 \%$ & $34.0 \%$ & $29.1 \%$ & $69.8 \%$ & $46.0 \%$ & $42.5 \%$ & $38.8 \%$ & $33.9 \%$ & $73.8 \%$ \\
\hline Population from 0.5 to 1 million & 8 & $47.2 \%$ & $43.0 \%$ & $38.6 \%$ & $32.8 \%$ & $69.4 \%$ & $45.8 \%$ & $42.0 \%$ & $38.0 \%$ & $32.5 \%$ & $70.9 \%$ \\
\hline $\begin{array}{c}\text { Population from } 1 \text { to } 1.5 \text { million } \\
\text { by region / income }\end{array}$ & 6 & $40.9 \%$ & $37.6 \%$ & $34.0 \%$ & $29.3 \%$ & $71.6 \%$ & $68.9 \%$ & $65.6 \%$ & $61.8 \%$ & $56.4 \%$ & $81.8 \%$ \\
\hline East Asia and Pacific & 12 & $50.9 \%$ & $45.1 \%$ & $39.9 \%$ & $34.5 \%$ & $67.8 \%$ & $74.2 \%$ & $69.6 \%$ & $64.5 \%$ & $60.0 \%$ & $80.8 \%$ \\
\hline Latin America and Caribbean & 10 & $74.9 \%$ & $72.2 \%$ & $68.2 \%$ & $62.4 \%$ & $83.3 \%$ & $75.4 \%$ & $73.0 \%$ & $69.5 \%$ & $63.9 \%$ & $84.8 \%$ \\
\hline Sub-Saharan Africa & 10 & $41.7 \%$ & $38.0 \%$ & $35.6 \%$ & $32.1 \%$ & $76.8 \%$ & $43.3 \%$ & $39.2 \%$ & $36.8 \%$ & $34.1 \%$ & $78.6 \%$ \\
\hline High-income countries & 12 & $23.0 \%$ & $19.9 \%$ & $17.9 \%$ & $14.9 \%$ & $64.6 \%$ & $24.9 \%$ & $21.9 \%$ & $20.1 \%$ & $17.0 \%$ & $68.5 \%$ \\
\hline \multicolumn{12}{|l|}{ Other Groups of Interest } \\
\hline Small Islands Developing States & 37 & $42.4 \%$ & $38.0 \%$ & $33.1 \%$ & $28.3 \%$ & $66.6 \%$ & $45.0 \%$ & $40.4 \%$ & $35.5 \%$ & $30.8 \%$ & $68.4 \%$ \\
\hline Population from 1.5 to 3 million & 15 & $20.9 \%$ & $18.4 \%$ & $15.6 \%$ & $13.2 \%$ & $63.4 \%$ & $25.0 \%$ & $21.9 \%$ & $18.2 \%$ & $15.2 \%$ & $61.0 \%$ \\
\hline Population from 3 to 4 million & 13 & $18.5 \%$ & $16.7 \%$ & $15.6 \%$ & $13.8 \%$ & $74.7 \%$ & $20.7 \%$ & $18.5 \%$ & $17.3 \%$ & $15.3 \%$ & $73.8 \%$ \\
\hline World average & 192 & $5.3 \%$ & $4.6 \%$ & $4.1 \%$ & $3.6 \%$ & $68.6 \%$ & $5.2 \%$ & $4.4 \%$ & $4.0 \%$ & $3.5 \%$ & $66.9 \%$ \\
\hline Total high-income countries & 41 & $3.5 \%$ & $2.9 \%$ & $2.6 \%$ & $2.3 \%$ & $64.7 \%$ & $3.8 \%$ & $3.1 \%$ & $2.8 \%$ & $2.4 \%$ & $64.1 \%$ \\
\hline Total developing countries & 151 & $7.4 \%$ & $6.6 \%$ & $5.9 \%$ & $5.2 \%$ & $71.1 \%$ & $7.8 \%$ & $6.9 \%$ & $6.2 \%$ & $5.4 \%$ & $69.8 \%$ \\
\hline
\end{tabular}

Source: Beine, Docquier and Rapoport (2006) 
Table 4. Brain drain in small states (year 2000)

\begin{tabular}{|c|c|c|c|c|c|}
\hline Country & $\mathrm{BD} 0+$ & $\mathrm{BD} 12+$ & BD 18+ & $\mathrm{BD} 22+$ & Population \\
\hline Tuvalu & $27.3 \%$ & $26.1 \%$ & $25.5 \%$ & $23.8 \%$ & 11468 \\
\hline Nauru & $34.5 \%$ & $28.0 \%$ & $23.4 \%$ & $19.8 \%$ & 12809 \\
\hline Palau & $26.1 \%$ & $24.1 \%$ & $22.3 \%$ & $18.5 \%$ & 20016 \\
\hline San Marino & $17.1 \%$ & $16.4 \%$ & $15.9 \%$ & $14.9 \%$ & 28503 \\
\hline Saint Kitts and Nevis & $78.5 \%$ & $76.3 \%$ & $72.0 \%$ & $65.3 \%$ & 38836 \\
\hline Marshall Islands & $39.4 \%$ & $39.4 \%$ & $39.3 \%$ & $39.2 \%$ & 57738 \\
\hline Antigua and Barbuda & $66.8 \%$ & $63.4 \%$ & $57.8 \%$ & $49.6 \%$ & 68320 \\
\hline Dominica & $64.2 \%$ & $61.2 \%$ & $57.4 \%$ & $51.2 \%$ & 69278 \\
\hline Andorra & $6.9 \%$ & $5.8 \%$ & $5.4 \%$ & $4.6 \%$ & 69865 \\
\hline Seychelles & $55.8 \%$ & $53.3 \%$ & $51.0 \%$ & $47.5 \%$ & 80832 \\
\hline Grenada & $85.1 \%$ & $83.7 \%$ & $81.2 \%$ & $76.9 \%$ & 89357 \\
\hline Kiribati & $23.1 \%$ & $22.0 \%$ & $21.2 \%$ & $20.7 \%$ & 100798 \\
\hline Tonga & $75.2 \%$ & $70.4 \%$ & $65.1 \%$ & $58.8 \%$ & 101000 \\
\hline Micronesia, Federated States & $37.8 \%$ & $37.4 \%$ & $36.9 \%$ & $34.8 \%$ & 107000 \\
\hline Saint Vincent \& Grenadines & $84.5 \%$ & $83.0 \%$ & $79.8 \%$ & $75.1 \%$ & 119000 \\
\hline Saint Lucia & $71.1 \%$ & $68.2 \%$ & $64.8 \%$ & $59.2 \%$ & 147000 \\
\hline Sao Tome and Principe & $22.0 \%$ & $21.5 \%$ & $21.2 \%$ & $20.0 \%$ & 149000 \\
\hline Samoa & $76.4 \%$ & $71.7 \%$ & $66.4 \%$ & $60.9 \%$ & 174000 \\
\hline Vanuatu & $8.2 \%$ & $6.7 \%$ & $5.8 \%$ & $4.7 \%$ & 195000 \\
\hline Belize & $65.5 \%$ & $61.5 \%$ & $54.8 \%$ & $47.0 \%$ & 238000 \\
\hline Barbados & $63.5 \%$ & $59.7 \%$ & $53.8 \%$ & $47.5 \%$ & 266000 \\
\hline Iceland & $19.6 \%$ & $18.3 \%$ & $17.4 \%$ & $15.8 \%$ & 282000 \\
\hline Maldives & $1.2 \%$ & $1.0 \%$ & $0.9 \%$ & $0.8 \%$ & 290000 \\
\hline Bahamas & $61.3 \%$ & $53.7 \%$ & $47.7 \%$ & $42.3 \%$ & 300000 \\
\hline Brunei & $15.6 \%$ & $13.3 \%$ & $11.5 \%$ & $9.7 \%$ & 335000 \\
\hline Malta & $57.6 \%$ & $53.3 \%$ & $49.7 \%$ & $44.1 \%$ & 389000 \\
\hline Suriname & $47.9 \%$ & $44.6 \%$ & $42.6 \%$ & $36.7 \%$ & 425000 \\
\hline Luxembourg & $8.0 \%$ & $7.1 \%$ & $6.7 \%$ & $5.8 \%$ & 436000 \\
\hline Solomon Islands & $6.4 \%$ & $5.0 \%$ & $4.1 \%$ & $3.5 \%$ & 437000 \\
\hline Cape Verde & $67.4 \%$ & $62.9 \%$ & $59.4 \%$ & $55.5 \%$ & 438000 \\
\hline Масао & $14.4 \%$ & $13.3 \%$ & $12.5 \%$ & $11.4 \%$ & 449000 \\
\hline Equatorial Guinea & $12.9 \%$ & $12.0 \%$ & $11.5 \%$ & $10.2 \%$ & 457000 \\
\hline Qatar & $2.5 \%$ & $2.3 \%$ & $2.1 \%$ & $1.9 \%$ & 582000 \\
\hline Djibouti & $11.0 \%$ & $9.2 \%$ & $8.3 \%$ & $7.5 \%$ & 666000 \\
\hline Bahrain & $4.9 \%$ & $4.3 \%$ & $3.9 \%$ & $3.5 \%$ & 677000 \\
\hline East Timor & $15.5 \%$ & $11.7 \%$ & $9.5 \%$ & $7.9 \%$ & 701000 \\
\hline Comoros & $21.9 \%$ & $19.5 \%$ & $17.3 \%$ & $13.1 \%$ & 706000 \\
\hline Guyana & $89.0 \%$ & $87.7 \%$ & $85.4 \%$ & $81.9 \%$ & 761000 \\
\hline Cyprus & $33.2 \%$ & $28.6 \%$ & $26.3 \%$ & $21.3 \%$ & 783000 \\
\hline Fiji & $62.2 \%$ & $56.4 \%$ & $50.9 \%$ & $44.5 \%$ & 813000 \\
\hline Mauritius & $56.1 \%$ & $52.2 \%$ & $49.4 \%$ & $45.1 \%$ & 1186000 \\
\hline Gabon & $14.7 \%$ & $11.6 \%$ & $10.0 \%$ & $8.4 \%$ & 1258000 \\
\hline Trinidad and Tobago & $79.3 \%$ & $76.6 \%$ & $73.0 \%$ & $67.5 \%$ & 1289000 \\
\hline Gambia & $63.2 \%$ & $62.5 \%$ & $62.1 \%$ & $60.4 \%$ & 1312000 \\
\hline Estonia & $11.5 \%$ & $10.8 \%$ & $10.3 \%$ & $9.4 \%$ & 1366000 \\
\hline Guinea-Bissau & $24.4 \%$ & $21.7 \%$ & $20.5 \%$ & $18.7 \%$ & 1367000 \\
\hline
\end{tabular}




\section{BILATERAL DATA}

Table 5 presents for the small states the number and share of skilled migrants by host region. None of the results are really surprising.

First, $66 \%$ or two thirds of skilled migrants from small states go to the US + Canada, followed by the EU15 with 23\% and Australia + New Zealand (10\%).

> Second, the first destination in 2000 of East Asia and Pacific skilled migrants was Australia + New Zealand (56\%) followed by USA + Canada (41\%), that of Latin America and Caribbean was USA + Canada (84\%) and the EU15 (16\%), that of SubSaharan Africa is the EU15 (57\%), followed by USA + Canada (27\%) and Australia + New Zealand (15\%), and that of high-income countries is $43 \%$ for both the EU15 and USA + Canada, and 12\% for Australia + New Zealand. Thus, the region whose skilled migration is the most concentrated across the host regions is Latin America and the Caribbean, followed by Sub-Saharan Africa, East Asia and the Pacific, and by highincome countries.

Third, as for evolution, the distribution across host regions has been fairly stable, with minimal changes in their shares of skilled immigrants from the various source regions between 1990 and 2000. This may attest to the strength of existing migrant networks in determining new migrants' destination. In other words, history matters - whether the network was formed because of small distance, large income differentials, past colonial ties, or other. 
Table 5. Small states brain drain by destination

\begin{tabular}{|c|c|c|c|c|c|}
\hline \multirow[b]{2}{*}{ DESTINATION } & \multicolumn{5}{|c|}{ Skilled emigrants in 2000} \\
\hline & OCDE & $\begin{array}{l}\text { To: } \\
\text { USA + } \\
\text { Canada }\end{array}$ & EU15 & $\begin{array}{l}\text { Australia + } \\
\text { N. Zealand }\end{array}$ & Others \\
\hline East Asia and Pacific & 76307 & $\begin{array}{c}31234 \\
41 \%\end{array}$ & $\begin{array}{c}1916 \\
3 \%\end{array}$ & $\begin{array}{c}43053 \\
56 \%\end{array}$ & $\begin{array}{l}104 \\
0 \%\end{array}$ \\
\hline Latin America and Caribbean & 375822 & $\begin{array}{c}315227 \\
84 \%\end{array}$ & $\begin{array}{c}58780 \\
16 \%\end{array}$ & $\begin{array}{c}1448 \\
0 \%\end{array}$ & $\begin{array}{c}366 \\
0 \%\end{array}$ \\
\hline Sub-Saharan Africa & 44493 & $\begin{array}{l}12206 \\
27 \%\end{array}$ & $\begin{array}{c}25269 \\
57 \%\end{array}$ & $\begin{array}{l}6554 \\
15 \%\end{array}$ & $\begin{array}{c}464 \\
1 \%\end{array}$ \\
\hline High-income countries & 113555 & $\begin{array}{c}49201 \\
43 \%\end{array}$ & $\begin{array}{c}48641 \\
43 \%\end{array}$ & $\begin{array}{c}13837 \\
12 \%\end{array}$ & $\begin{array}{c}1876 \\
2 \%\end{array}$ \\
\hline \multirow[t]{2}{*}{ Total } & 634100 & $\begin{array}{c}417289 \\
66 \%\end{array}$ & $\begin{array}{c}147626 \\
23 \%\end{array}$ & $\begin{array}{c}66107 \\
10 \%\end{array}$ & $\begin{array}{c}3079 \\
0 \%\end{array}$ \\
\hline & \multicolumn{5}{|c|}{ Skilled emigrants arrived after age 22 in 2000} \\
\hline $\begin{array}{ll} & \text { DESTINATION } \\
\text { SOURCE } & \end{array}$ & OCDE & $\begin{array}{l}\text { To: } \\
\text { USA + } \\
\text { Canada }\end{array}$ & EU15 & $\begin{array}{l}\text { Australia }+ \\
\text { N. Zealand }\end{array}$ & Others \\
\hline East Asia and Pacific & 38851 & $\begin{array}{c}17152 \\
44 \%\end{array}$ & $\begin{array}{c}1391 \\
4 \%\end{array}$ & $\begin{array}{c}20210 \\
52 \%\end{array}$ & $\begin{array}{l}77 \\
0 \%\end{array}$ \\
\hline Latin America and Caribbean & 208565 & $\begin{array}{c}171624 \\
82 \%\end{array}$ & $\begin{array}{c}35910 \\
17 \%\end{array}$ & $\begin{array}{c}712 \\
0 \%\end{array}$ & $\begin{array}{c}208 \\
0 \%\end{array}$ \\
\hline Sub-Saharan Africa & 29313 & $\begin{array}{l}8412 \\
29 \%\end{array}$ & $\begin{array}{c}17423 \\
59 \%\end{array}$ & $\begin{array}{c}3096 \\
11 \%\end{array}$ & $\begin{array}{c}170 \\
1 \%\end{array}$ \\
\hline High-income countries & 66301 & $\begin{array}{c}28013 \\
42 \%\end{array}$ & $\begin{array}{c}29038 \\
44 \%\end{array}$ & $\begin{array}{c}7896 \\
12 \%\end{array}$ & $\begin{array}{c}925 \\
1 \%\end{array}$ \\
\hline \multirow[t]{2}{*}{ Total } & 362082 & $\begin{array}{c}232161 \\
64 \%\end{array}$ & $\begin{array}{l}94476 \\
26 \%\end{array}$ & $\begin{array}{l}33073 \\
9 \%\end{array}$ & $\begin{array}{c}1532 \\
0 \%\end{array}$ \\
\hline & Skilled emi & $\begin{array}{l}\text { rants in } 1990 \\
\text { |To: }\end{array}$ & & & \\
\hline SOURCE $\quad$ DESTINATION & OCDE & $\begin{array}{c}\text { USA + } \\
\text { Canada }\end{array}$ & EU15 & $\begin{array}{l}\text { Australia }+ \\
\text { N. Zealand }\end{array}$ & Others \\
\hline East Asia and Pacific & 48797 & $\begin{array}{c}15718 \\
32 \%\end{array}$ & $\begin{array}{l}736 \\
2 \%\end{array}$ & $\begin{array}{c}32329 \\
66 \%\end{array}$ & $\begin{array}{l}41 \\
0 \%\end{array}$ \\
\hline Latin America and Caribbean & 217056 & $\begin{array}{c}178872 \\
82 \%\end{array}$ & $\begin{array}{c}36608 \\
17 \%\end{array}$ & $\begin{array}{c}1200 \\
1 \%\end{array}$ & $\begin{array}{c}275 \\
0 \%\end{array}$ \\
\hline Sub-Saharan Africa & 26587 & $\begin{array}{c}6763 \\
25 \%\end{array}$ & $\begin{array}{c}11173 \\
42 \%\end{array}$ & $\begin{array}{c}8393 \\
32 \%\end{array}$ & $\begin{array}{l}86 \\
0 \%\end{array}$ \\
\hline High-income countries & 81315 & $\begin{array}{c}33642 \\
41 \%\end{array}$ & $\begin{array}{c}32198 \\
40 \%\end{array}$ & $\begin{array}{c}14472 \\
18 \%\end{array}$ & $\begin{array}{c}452 \\
1 \%\end{array}$ \\
\hline Total & 373885 & $\begin{array}{c}234995 \\
63 \%\end{array}$ & $\begin{array}{c}80748 \\
22 \%\end{array}$ & $\begin{array}{c}56488 \\
15 \%\end{array}$ & $\begin{array}{c}803 \\
0 \%\end{array}$ \\
\hline
\end{tabular}




\section{CONCLUSION}

This paper presented evidence on the brain drain, focusing on small states. We found that small states i) had three out of seven skilled individuals (43\%) living outside their country of origin in 2000; ii) had a brain drain level that amounts to over 5 times the brain drain in developing countries as a whole, 12 times that in high-income countries as a whole, and 8 times that of the world, iii) that it declined between 1990 and 2000, iv) that their schooling gap was much smaller than that for developing countries as a whole and similar to that for the world as a whole and, and v) that it declined for all small state groups and other country groups, except for small high-income states and for high-income countries as a whole.

When correcting for the age of entry, we found that in small states in 2000, skilled emigrants arriving in the host country after the age of 22 (and who presumably obtained their university education in their country of origin) amounted to about $70 \%$ of all skilled migrants (including those who obtained their university education abroad). This ratio was similar for all developing countries as well as for the world average, and it declined between 1990 and 2000 in all small states groups while increasing in all other country groups.

We also found that the distribution of migrants across host regions has been fairly stable, with minimal changes in their shares of skilled immigrants from the various source regions between 1990 and 2000. We hypothesized that this reflected the strength of existing migrant networks in determining new migrants' destination, with past migration patterns strongly affecting subsequent migration decisions. This is because the networks themselves have a strong impact and because a number of variables found to affect the incentive to migrate to a certain region - compared to other regions or staying home - are invariant with respect to time, including distance and colonial past, while another variable, namely income differential, did not change significantly over the period.

The negative trend in the brain drain is unlikely to be sufficient to stop the hemorrhage in the poorer small states anytime in the near or foreseeable future, and implementing some policies to slow it down might be in order. However, few policies that would succeed in reducing the brain drain seems have been found, and some might even be counterproductive. ${ }^{24} \mathrm{~A}$ strategy

\footnotetext{
24 For instance, some African countries have given degrees in certain fields that are not recognized internationally in order to retain more professionals in the country. However, this policy is likely to have a smaller effect than, if not opposite to, the intended one. The reason is that the policy is likely to reduce the total
} 
from which source countries would benefit is by establishing programs, in cooperation with host countries, to provide fellowships to study abroad, on the condition that the recipients return home after graduation for a specified period of time before having the option to emigrate again. ${ }^{25}$ Countries lacking the resources to do so would have to obtain financing from foreign sources (e.g., the host countries involved). Some students might decide not to return and the program's success would depend on agreements between source and host countries to prevent such occurrences, such as the host country committing not to renew the visa of those refusing to return after completing their studies or internship.

Another strategy that should help convince some graduates to remain home, and some migrants and students abroad to return home would be to improve conditions for skilled labor in the public sector. This would also improve public services by raising the quality of the staff and reducing the extent of absenteeism. Such a policy could be conducted together with the previous one and might also require external support.

Finally, source countries would benefit if skilled migrants' hiring contracts abroad could be made temporary, possibly stipulating that these migrants would be able to return after a specified period of time in their home country.

number of students in those fields, and to raise the number of those who study and remain abroad because they tend to be more successful in the host countries than those who migrate after completing their study at home.

${ }^{25}$ Such circular migration would also benefit host countries because it would reduce the extent to which migrants reneged on their commitment to leave after graduation (Schiff 2007). 


\section{REFERENCES}

Adams, R. (2003), "International migration, remittances and the brain drain: a study of 24 labor-exporting countries”, World Bank Policy Research Working Paper No. 2972.

Barro, R.J. and J.W. Lee (2000), “International Data on Educational Attainment: Updates and Implications”, CID Working Papers 42, Center for International Development (Harvard University).

Bhorat, H., J-B. Meyer and C. Mlatsheni (2002), "Skilled labor migration from developing countries: study on South and Southern Africa", ILO International Migration Papers, International Labor Office, Geneva.

Carrington, W.J. and E. Detragiache (1998), “How big is the brain drain?”, IMF Working paper WP/98/102.

Cohen and Soto (2001), “Growth and Human Capital: Good Data, Good Results,” CEPR Discussion Papers 3025, CEPR.

Debuisson, M., F. Docquier, A. Noury and M. Nantcho (2004), "Immigration and aging in the Belgian regions,” Brussels Economic Review (2004), Special issue on skilled migration, 47(1), 139-158.

De la Fuente, A. and R. Domenech (2002), "Human capital in growth regressions: how much difference does data quality make? An update and further results," CEPR Discussion Paper No. 3587.

Docquier, F. et A. Marfouk (2006), "International migration by educational attainment (19902000)”, in Ozden, C. et M. Schiff (eds), International Migration, Remittances and the Brain Drain, Chap 5, Palgrave-Macmillan.

Fargues, Philippe (2006) “...”in Ozden, C. et M. Schiff (eds), op. cit.

Lucas, R.B. (1988), “On the mechanics of economic development,” Journal of Monetary Economics.

Ozden, C. and M. Schiff (2006), International Migration, Remittances and the Brain, Palgrave-Macmillan.

Rosenzweig, M.R. (2005), “Consequences of migration for developing countries”, Paper prepared for the UN Conference on International Migration and Development, Population Division.

Schiff, M. (2007), "Optimal Immigration Policy: Permanent, Guest-Worker, or Mode IV?" IZA Discussion Paper 3083, September 2007, http://ftp.iza.org/dp3083.pdf. 